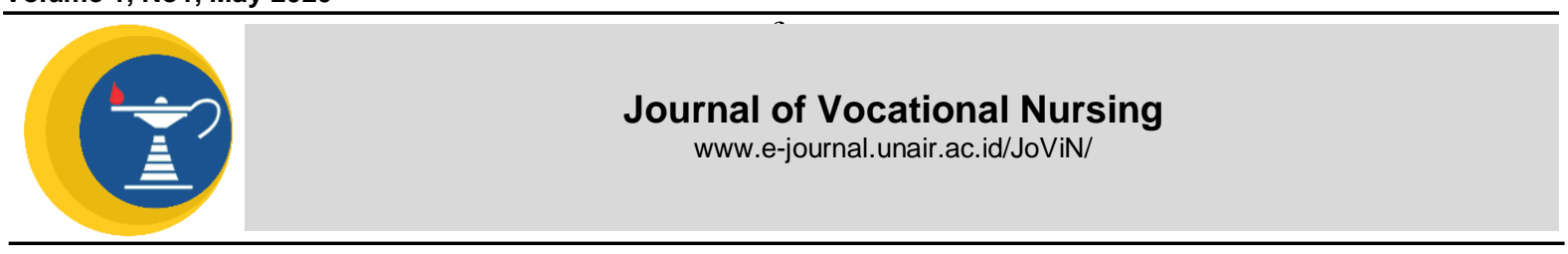

\title{
THOUGHT STOPPING ENHANCING SELF-ESTEEM OF PEOPLE WITH SCHIZOPHRENIA
}

Research Report

\author{
Sulastri ${ }^{1}$, Andi Thahir ${ }^{2}$, Rohayati ${ }^{3}$ \\ ${ }^{1}$ Poltekkes Tanjungkarang, Indonesia, ${ }^{2}$ Jurusan Bimbingan dan Konseling, Universitas Islam Negeri \\ Raden Intan Lampung, Indonesia, ${ }^{3}$ Poltekkes Tanjungkarang, Indonesia
}

\section{ABSTRACT}

Introduction: A person who has low self-esteem sees the environment in a negative way and considers it a threat. Schizophrenias patients with negative symptoms generally show a feeling of inferiority, this condition is a problem because of the cause of other problems, such as social isolation. The purpose of this research was to analyze the effect of giving thought stopping to selfesteem people with schizophrenia.

Methods : This research uses quantitative approach the method used was the experimental design of pretest-posttest with control design. The population is the patient who was treated at the Custody. Sampling method in this research is by purposive sampling. Total sample is 90 respondents, divided into two groups, Intervention group 30 and control group 60 respondents. Measurement of data with client's self-esteem observation sheets before and after therapy..

Results : The result of bivariate analysis was done using t-test obtained by $p$ value $<0,005$. There is a significant difference in patient self-esteem in the control group and intervention group after thought stopping.

Conclusion: These results suggest there is influence of thought stopping with patient self esteem. Sex, length of illness and treatment history are not confounding factors. It is recommended to use thought stopping as one of the actions of nursing, especially on clients with self esteem problems.

\section{ARTICLE INFO}

Recived 25 December 2019

Accepted 10 May 2020

Online 29 May 2020

*Correspondence:

Sulastri

*Email:

sulastri@poltekkes-tjk.ac.id

Keywords:

People with Schizophrenia, Self

- Esteem, Thought Stopping

\section{INTRODUCTION}

Mental health is an integral part and becomes the most important element in human life. Mental health is a prosperous state that encompasses happiness, satisfaction, acceptance, optimism and the hope that one has (Stuart, 2013). Healthy indicators of the soul include a positive attitude toward self, grow, develop, have self-actualization, wholeness, freedom of self, have perception as reality and skill in adapt to environment (Stuart \& Laraia, 2010). Schizophrenias are defined as clinically important syndromes or behaviors that occur in a person and are associated with distress (e.g. pain symptoms) or disability / damage to one or more important function areas (Sheila L, 2008).

Based on data from Riskesdas 2018 the prevalence of severe schizophrenia in DIY
(2.7\%), Aceh (2.7\%), South Sulawesi (2.6\%), Bali (2.3\%), Central Java (2.3\%), Lampung $(0.8 \%)$. The proportion of households with severe immunosuppressed ART was calculated against 1,655 households with severe mental illness. The proportion of households who have had ART for schizophrenias was $14.3 \%$. Prevalence of population with emotional schizophrenia nationally $6 \%$, province with highest prevalence of schizophrenia that is Central Sulawesi $(11,6 \%)$, South Sulawesi $(9,3 \%)$, West Java $(9,3 \%)$, DIY (8, $1 \%)$, NTT $(7.8 \%)$, Lampung $(1,2 \%)$ Seeing the high number of schizophrenias in Indonesia is a serious problem for the health and nursing world of Indonesia. Such disturbances include difficulty getting along, withdrawing from reality, anxiety, panic, destroying / hurting others, more 
lowering / low self-esteem (Kurniawan \& Sulistyarini, 2016).

Low self esteem is a sadness or a feeling of endless grief(Kumar, Lal, \& Bhuchar, 2014; Stuart \& Laraia, 2010; Suerni, Anna, \& Helena, 2013). One's self-esteem is derived from oneself and others (Srisayekti, Setiady, \& Sanitioso, 2015). Low self-esteem disorder will occur if loss of affection, threatening other people's treatment, and bad interpersonal relationships (Fatkhul Mubin, 2009; Febriana et al., 2016). A person's self-esteem is in a high to low range. Individuals who have high selfesteem face the environment effectively to change and tend to feel secure (Arshad, Muhammad, \& Mahmood, 2015). Individuals who have low self-esteem see the environment in a negative way and perceive it as a threat (Febriana et al., 2016; Wakhid et al., 2013).

Low self-esteem is a condition experienced by individuals with psychosocial problems that are presented subjectively with a negative assessment of self (Depkes, RI, 2000 on (Fatkhul Mubin, 2009). According to Harter (1993) \& Rosenberg (1981) on (Bint-E Tahir, Inam, \& Raana, 2015) important self-esteem concepts during adolescence and support of social relationships are considered important and play an important role in the development of self-esteem during adolescence (Afari, Ward, $\&$ Khine, 2012). The search of identity ego is on the climax during teenage, as a young man who struggle to find out who he is. The rise of puberty, teenagers seek a new role in finding their sexual identity, ideology, and occupation (Bint-E Tahir et al., 2015). In the search, Teenagers draw from a variety of previous selfimages that have been accepted and rejected. This condition is related to adolescent selfesteem. Principle plays an important role in the search process self identity in adolescence (Bint-E Tahir et al., 2015), because it can help teenagers recognize themselves, so it can help improve self-confidence and will facilitate adolescents in making adjustments to the environment. Self-esteem is The global evaluative dimension of the self (Naseer et al., 2014; Uba, Yaacob, Talib, Mofrad, \& Abdullah, 2013). Self-esteem is also referred to as selfworth or self-image. For example, a child may feel that he is not just a human being, but also as a good human being (According to Santrock 2007, Feist and Feist 2008, in (Aliyah \& Denok, 2015).

Functional ability of some patients low self esteem is one of the problems in living everyday life. Disruption of functional capacity of all organs of the body is resulting from lack of interaction or decreased confidence that limits itself in normal activities. According to Harter \&
Rosenberg in (Srivastava \& Joshi, 2014) Selfesteem is associated with depression, anxiety, motivation and general satisfaction with one life. Patients treated At Mental Hospital with low self esteem generally do not care about their appearance and are difficult to open up and interact with their surrounding environment (Pramujiwati, Keliat, \& Wardani, 2013). It needs nurse encouragement to motivate patients to make patients self-sufficient, especially for the formation of better self-concept (Dimitriadou, 2014; Maheshwari \& Gill, 2015; Valizadeh et al., 2016). One attempt to encourage the motivation of patients with low self-esteem is with non medication therapy, such as using thought stopping therapy (S \& Handayani, 2014).

Thought stopping is a cognitive behavioral psychotherapeutic technique aimed at changing the mind of the patient (Rofiq, 2012). Thought stopping provides the patient with the skills to be able to self-instruct (stop swap committing) to stop negative thoughts through the presence of stimuli or stimulus shock (Fortinash \& Worret, 2005). The results of Tang and De Rubeis (1999) research in (Agustratika \& Nasution, 2011) suggest that Thought stopping is one of the cognitive behavioral psychotherapy that can be used to help patients change the thinking process. Patients with low self-esteem generally internalize their low selfesteem. Based on pre-survey data on July 25, 2015 at the Sakti Partners Rehabilitation Clinic, Gedong Tataan, Pesawaran District of Lampung Province from 29 patients, 16 (60\%) of whom experience chronic low self-esteem. The purpose of this research was to analyze the effect of giving thought stopping to self-esteem people with schizophrenia.

\section{MATERIALS AND METHODS}

The research used quantitative research type with quasi experiment design pretest and posttest with control group with thoughtstopping intervention that is comparing two groups of patients with low self esteem problem. This study was conducted to determine changes in patient self-esteem after therapy. Furthermore the ability will be compared in the intervention and control group. Group I: the group that received thought stopping intervention with 4 sessions and each session will be 2x meetings; Group II: a group that did not receive thought-knopping intervention, but received generalist therapy. The total population of the study was all patients treated in rehabilitation center. Ethics test has been conducted by the Tanjungkarang Polytechnic Ethics Study Team. 
The sample was determined by using purposive sampling technique from patient population with schizophrenia which fulfilled the following inclusion criteria: 1) There is a history of low self-esteem; 2) No physical problems; 3) Can follow directions, good attention; 4) Cooperative; 5) Follow therapy to completion. Exclusion criteria: 1) Chronic Low Self-Esteem; 2) No diseases can interfere with the patient's attention; 3) Can communicate both ways; 4) Be able to follow the rules during therapy / quiet; 5) Willing to follow the rules during therapy. The instrument used was the instrument developed by the researcher.
This study will involve 90 respondents divided into 30 respondents as intervention group (group I) and 60 respondents, as control group (group II). The process of data collection is done by identifying patients with schizophrenia with low self esteem problems by doing pre test. Furthermore, the researcher and the team were doing stopping in the intervention group as much as 4 sessions, each session was two meetings. After the therapy is done, then the two groups are re-measured to determine the patient's self-esteem and signs and symptoms after therapy.

\section{RESULTS}

The results of the analysis after the intervention showed a difference in the patient's self-esteem in the intervention group with the control group after therapy $(p=0.0001)$. The patient's self-esteem in the intervention group was higher $($ mean $=21.53)$ than the control group $($ mean $=11.58)$.

Table 1 Self-Esteem Intervention Before and After Thought Stopping

\begin{tabular}{cccccc}
\hline Group & Mean & SD & Min & Max & $\boldsymbol{P}$ - value \\
\hline Before & 11,35 & 2,596 & 4 & 16 & 0,280 \\
After & 11,58 & 2,580 & 5 & 16 & \\
\hline
\end{tabular}

From table 1 it can be seen that in the pretest and posttest intervention groups there is a difference with the difference of 9.4, the p-value obtained is smaller than 0.05 , so it can be concluded that there is a significant difference in the patient's self-esteem in the intervention group between before and After thought stopping.

Table 2 Frequency Distribution of Self-Esteem Frequency of Patients in the Control Group Before and After Thought Stopping

\begin{tabular}{cccccc}
\hline Group & Mean & SD & Min & Max & $\boldsymbol{p}$ - value \\
\hline Before & 11,35 & 2,596 & 4 & 16 & 0,280 \\
After & 11,58 & 2,580 & 5 & 16 & \\
\hline
\end{tabular}

From table 2 it can be seen that the score of ability in the control group score of ability when pretest and post test no difference. The $p$ value is more than 0.05 , so it can be concluded that there is no difference in the patient's self-esteem before and after therapy in the intervention group.

Table 3 Self-Esteem Patients in the Intervention and Control group before and after Thought Stopping

\begin{tabular}{cccccc}
\hline Group & Mean & SD & Min & Max & P-value \\
\hline Intervention & 21,53 & 3,511 & 16 & 16 & 0,000 \\
Control & 11,58 & 2,580 & 5 & 27 & \\
\hline
\end{tabular}

From table 3 it can be seen that the score of ability in the intervention group and the control group is different from the difference of 9.95 . The analysis obtained $p$-valued less than 0.05 , so it can be concluded that there is a significant difference in patient self-esteem in the control group and intervention group after thought stopping.

\section{DISCUSSION}

From the results of the research it is found that when pretest intervention and control group showed self-esteem patient who do not much different, with average value in experiment group that is equal to 12,1 with minimum value 5 and maximum value 16 . While in control group mean value of self value Patient is 11.35 with a minimum value of 5 and a maximum value of 11 .

According to (Yosep, 2009), low selfesteem is negative judgment about oneself. Patient cannot see the ability possessed as a positive and unique. Patients think themselves lower than others. This condition causes the patient to withdraw, do not want to associate 
with others and often daydreaming. Hard to talk and quiet.

According to the researchers, the average value of self-esteem of patients who are not much different in the experimental and control groups due to the absence of treatment given to the respondents is Thought Stopping. From the research result, it is found that when the posttest in the experimental and control group shows the self-esteem of patient who is quite different, with the average value in the experimental group that is 31 with the minimum value 23 and the maximum value 40 . While in the control group the average value of the patient's self-esteem is of 11.94 with a minimum value of 5 and a maximum value of 22 .

Based on Yosep (2014), A negative selfesteem can occur because thinking errors often have a snowball effect on the patient. Initially the problem is small, but over time it is difficult to solve. The technique to stop thinking about it is very well used when clients start thinking of something as a problem. Thought stopping helps the patient to illustrate that the problem is over (S \& Handayani, 2014). Fancy that the bell stops ringing. Fancy a brick on the wall used to stop dysfunctional thinking.

According to the researchers, the average value of self-esteem of patients is quite different in the experimental and control groups due to the treatment given to the respondents is thought stopping. The thought-stopping treatment can stimulate the patient to control his hallucinations by imagining things to stop dysfunctional thinking.

The results showed that the pretest and posttest experimental group's self esteem experienced significant increase in value, seen from the mean increased value from 17.5 to 31 . The paired sample t-test result obtained $p$-value $=0,000$, which means there is a difference or There was a significant effect of patient selfesteem on the experimental group during pretest and posttest.

Patient self-esteem in the control group during pretest and posttest did not show significant increase in value, seen from the mean value only increased from 11.88 to 11.94 . The result of paired sample t-test is obtained $p$ value $=0,889$, meaning there is no difference or no significant influence of patient self esteem in control group during pretest and posttest. The prerequisite test results show that the results of pretest and posttest data in the experimental and control groups are normal distributed and homogeneous, so it is feasible to test the hypothesis using independent t-test. The result of t-test obtained that the value at the time of posttest has a significant difference. This suggests that the research hypothesis is acceptable, namely: "there is the influence of thought-stopping therapy on patient selfesteem".

According to (Agustratika \& Nasution, 2011), which is contained in the draft therapist module, the termination of thought (Thought Stopping) is one example of cognitive behavioral psychotherapy techniques that can be used to help change the thinking process (Supriati, Keliat, \& Nuraini, 2014). Changing the process of thinking is important for a therapist to maintain the feelings of clients and can strongly influence the pattern and process of thinking. Thought stopping is a self-instructional skill to stop negative thoughts through the presence of stimuli or stimuli that startle (Supriati et al., 2014).

This research is in line with the research conducted by (Twistiandayani \& Widati, 2013) with the title of the influence of thought stopping therapy on the ability to control hallucinations in schizophrenic patients in Mental poly RS Gresik Regency in 2013. The sample determination with purposive sampling of 30 outpatients in poly RS Gresik District in 2013. The variables in the study are independent variables: thoughtstopping therapy and dependent variable: the patient's ability to control hallucinations. The data collection is using observation sheet and structured interview. Data analysis using Wilcoxon Sign Rank Test, so $\mathrm{HO}$ rejected and $\mathrm{Ha}$ accepted. This means that there is the influence of thought-stopping therapy on patient self-esteem in schizophrenic patients in mental poly RS Gresik Regency in 2013.

In addition, a study similar to the research (Agustratika \& Nasution, 2011), the results of this study indicate mild anxiety levels in families with school-aged children who underwent chemotherapy in the given group and moderate anxiety levels in the group were given thought-stopping. This shows that thought stopping affects the patient's selfesteem and anxiety level.

According to the researchers, selfesteem patients in schizophrenia patients can be influenced by the treatment conducted by researchers, namely therapy thought stopping. In non-treated respondents, the increase of patient's self-esteem value did not occur significantly, at pretest time of 11.88 and posttest of 11.94 , which only increased by 0.06 . In contrast, respondents treated (experiment) increased the value of self-esteem of patients, i.e. at the time of pretest of 13.63 and posttest of 30.5 which means only increased as much as 16.67. Increasing the patient's self-esteem in the hallucinatory patient after receiving treatment prior to treatment is due to the treatment given during thought stopping 
therapy can stimulate the cognitive and psychomotoric patient in controlling the hallucinations by helping to stop negative or maladaptive thoughts that arise by focusing thoughts on something. In addition, the patient's thought stopping therapy is also stimulated to perform positive activities in controlling the hallucinations. Patients' experiences on the treatment of thought-stopping therapy are then new knowledge for the patient, so that with the new knowledge they have the ability to control the hallucinations.

In accordance with the results of bivariate analysis, it is known that giving thought implant treatment requires a positive impact on the patient's ability to increase his self-esteem. This is known from the increase in self-esteem of patients in the intervention group is quite significant. Positive impact of increased patient ability becomes higher than the average value increases. This is because patients who have received thought-stopping therapy have a better degree of readiness in assessing their positive aspects. Providing a stimulus in thought-stopping therapy can improve the provision of patient ability to take positive action if the self-redness returns. Thus, it can be concluded that there is the influence of thoughtstopping therapy on patient self-esteem in patients.

The study found that some respondents in the experimental group had an increased value during posttest although the increase was not significant, according to the researchers this was due to the knowledge gained from his experience during pretest so that the patient's self-esteem slightly increased. The results of this study is expected nurses can do psychotherapy, especially thought stopping therapy, and family support needed so that patients can routinely follow psychotherapy activities especially thinking stopping so that patients can control hallucinations in positive ways.

The statistical test results on confounding factors, i.e. sex, medical history and length of client illness, show all factors not related to patient's self-esteem. The results showed most of the respondents were male. The results of the analysis also show that there is no relationship between sex and patient selfesteem, so it can be concluded that gender is not a confounding factor affecting family ability. This result is not in line with the opinion (Stuart \& Laria, 2005), that gender affects a person point of view of a problem, generally female clients use a lot of feelings, so they are wiser in facing a problem.

The treatment history is not related to the patient's self-esteem. The results showed that most patients routinely perform treatment. The statistical test results there is no relationship between sex with patient self esteem. These results suggest that gender is not a confounding factor. The results of this study are not in line with the results of the study. Medical history related to the health education obtained. According to (Notoatmodjo, 2007), through education one's insight will be increased. There was no correlation between treatment history and patient's self esteem. According to the researcher, during treatment, the patient got more information about medical aspect or treatment. The length of sick clients is not related to the patient's self-esteem. The results showed that the average length of clients sick 6 years. The statistical test results there is no relationship between the length of the sick client with the patient's self-esteem. These results indicate that long ill clients are not a confounding factor. In general, the information provided by health workers is largely medicaloriented. Information on health education how to care is still very limited given. Besides, the length of the client's illness also gives a feeling of saturation for the control, sometimes the treatment is not done routinely, these conditions certainly gives an impact because of little information received by patient and family. Research limitations: Respondents are schizophrenic patients, cognitive fluctuations and responses are also influenced by other problems such as hallucinations etc.

\section{CONCLUSION}

There is a meaningful influence on thought stopping on the self-esteem of mental patients. There is no relationship between sex, medication history, and length of sick clients, which means these three factors are not a confounding factor of the patient's self-esteem. It is advisable to develop psychotherapy in the care of family nursing with clients of schizophrenias, by cooperating with educational institutions and mental health organizations for the application of community mental health nursing.

\section{REFERENCES}

Afari, E., Ward, G., \& Khine, M. S. (2012). Global self-esteem and self-efficacy correlates: Relation of academic achievement and self-esteem among Emirati students. International Education Studies, 5(2), 49-57. https://doi.org/10.5539/ies.v5n2p49

Agustratika, \& Nasution. (2011). Pengaruh Thought Stopping terhadap Tingkat Kecemasan Keluarga dengan Anak Usia Sekolah yang Menjalani Kemoterapi di 
RSUPN Dr Cipto Mangunkusumo. In Spesialis Keperawatan Jiwa. Jakarta: FIK UI.

Aliyah, \& Denok, S. (2015). Penerapan Terapi Multimodal dengan Teknik Thought Stopping dan Desensitisasi Sistematik untuk Meningkatkan Harga Diri yang Rendah pada Siswa Kelas VIII-E SMPN 4 Pasuruan. Jurnal Bk UNESA, 5(3).

Arshad, M., Muhammad, S., \& Mahmood, K. (2015). Self-Esteem \& Academic Performance Among University students. Journal of Education and Practice, 6(1), 156-162.

Bint-E Tahir, W., Inam, A., \& Raana, T. (2015). Relationship between Social Support and Self-Esteem of Adolescent Girls. IOSR Journal Of Humanities And Social Science, 20(2), 42-46. https://doi.org/10.9790/0837-20254246

Dimitriadou, A. (2014). The Concept of SelfEsteem in Nursing Education and its Impact on Professional Behaviour. International Journal of Caring Sciences, $7(1), 6-11$.

Fatkhul Mubin, M. (2009). Penerapan Terapi spesialis Keperawatan Jiwa: Terapi Kognitif pada Harga Diri Rendah di RW 09, 11, dan 13 Kelurahan Bubulak Bogor. Jurnal KePerawatan, 2(2), 28-35.

Febriana, B., Poeranto, S., Kapti, R. E., IImu, F., Universitas, K., Sultan, I., ... Brawijaya, U. (2016). Pengaruh terapi kognitif terhadap harga diri remaja korban bullying. Jurnal IImu Keperawatan, 4(1), 73-84.

Fortinash, K. M., \& Worret, P. A. H. (2005). Psychiatric Mental Health Nursing (3 rd). USA: Mosby, Inc.

Kumar, R., Lal, R., \& Bhuchar, V. (2014). Impact of social support in relation to selfesteem and aggression among adolescents. International Journal of Scientific and Research Publications, 4(12), 1-5.

Kurniawan, Y., \& Sulistyarini, I. (2016). Komunitas Sehati (Sehat Jiwa dan Hati) Sebagai Intervensi Kesehatan Mental Berbasis Masyarakat. INSAN Jurnal Psikologi Dan Kesehatan Mental, 1(2), 112-124.

https://doi.org/10.20473/jpkm.V1I22016.1 12-124

Maheshwari, S. K., \& Gill, K. K. (2015). Relationship of Assertiveness and Self Esteem among Nurses. International Journal of Health Sciences and Research (IJHSR), 5(6), 440-449.

Naseer, M., Shabir, G., Umar, H. M., Shabir, S. A., Nadvi, N. A., Hayat, A., \& Azher, M.
(2014). Effects of Social Support on SelfEsteem Amongest the Students of U.O.S Sargodha. International Journal of Academic Research and Reflection, 2(2), 20-29.

Notoatmodjo. (2007). Promosi Kesehatan \& IImu Perilaku. Jakarta: Rineka Cipta.

Pramujiwati, D., Keliat, B. A., \& Wardani, Y. I. (2013). Pemberdayaan Keluarga dan Kader Kesehatan Jiwa dalam Penanganan Pasien Harga Diri Rendah Kronik dengan Pendekatan Model Precede L.Green di RW 06, 07 dan 10 Tanah Baru Bogor Utara. Jurnal Keperawatan Jiwa, 1(2).

Rofiq, A. A. (2012). Terapi Islam Dengan Strategi Thought Stopping Dalam Mengatasi Hypochondriasis. Jurnal Bimbingan Dan Konseling, 2(1), 65-74.

S, E. C., \& Handayani, S. (2014). Pengaruh Cognitive Behavioral Therapy (CBT) terhadap Perubahan Kecemasan, Mekanisme Koping, Harga Diri pada Pasien Gangguan Jiwa dengan Skizofrenia di RSJD Surakarta. Jurnal Terpadu IImu Kesehatan, 3(1), 41-50.

Sheila L, V. (2008). Buku Ajar Keperawatan Jiwa. Jakarta: EGC.

Srisayekti, W., Setiady, D. A., \& Sanitioso, R. B. (2015). Harga-diri ( Self-esteem ) Terancam dan Perilaku Menghindar. Jurnal Psikologi, 42(2), 141-156.

Srivastava, R., \& Joshi, S. (2014). Relationship between Self-concept and Self-esteem in adolescents. International Journal of Advanced Research, 2(2), 36-43.

Stuart, \& Laraia. (2010). Principle and Practice Of Psychiatric Nursing. St. Louise: L Mosby. Inc.

Stuart, \& Laria. (2005). Principles \& Practice of Psychiatric Nursing (7th Editio). St. Louise: Mosby.

Suerni, T., Anna, B., \& Helena, N. (2013). Penerapan Terapi Kognitif dan Psikoedukasi Keluarga pada Klien Harga Diri Rendah di Ruang Yudistira Rumah Sakit Dr. H. Marzoeki Mahdi Bogor Tahun 2013. Jurnal Keperawatan Jiwa, 1(2), 161-169.

Supriati, L., Keliat, B. A., \& Nuraini, T. (2014). Pengaruh Terapi Thought Stopping dan Progressve Muscle Relaxation terhadap Ansietas pada Klien dengan Gangguan Fisik di RSUD Dr. Soedono Madiun. Jurnal Keperawatan STIKES Hang Tuah Surabaya, 3(3), 191-203.

Twistiandayani, R., \& Widati, A. (2013). Pengaruh Terapi Tought Stopping terhadap Kemampuan Mengontrol Halusinasi pada Pasien Skizofrenia. 
Prosiding Konferensi Nasional PPNI Jawa Tengah 2013, 240-242.

Uba, I., Yaacob, S. N., Talib, M. A., Mofrad, S., \& Abdullah, R. (2013). Effect of SelfEsteem in the Relationship between Stress and Substance Abuse among Adolescents: A Mediation Outcome. International Journal of Social Science and Humanity, 3(3), 214-217. https://doi.org/10.7763/IJSSH.2013.V3.2 30

Valizadeh, L., Zamanzadeh, V., Badri Gargari, R., Ghahramanian, A., Jabbarzadeh Tabrizi, F., \& Keogh, B. (2016). SelfEsteem Challenges of Nursing Students: An Integrative Review. Research and Development in Medical Education, 5(1), 5-11.

https://doi.org/10.15171/rdme.2016.003
Wakhid, A., Hamid, A. Y. S., Keperawatan, F. I., Indonesia, U., Keperawatan, F. I., \& Indonesia, U. (2013). Penerapan Terapi Latihan Ketrampilan Sosial pada Klien Isolasi dan Harga Diri Rendah dengan Pendekatan Model Hubungan Interpersonal Peplau di RS DR Marzoeki Mahdi Bogor. Jurnal Keperawatan Jiwa, 1(1), 34-48. Retrieved from http://jurnal.unimus.ac.id/index.php/JKJ/a rticle/view/911/965

Yosep, I. (2009). Buku Ajar Keperawatan Jiwa (Edisi Revi). Jakarta: PT. Refika Aditama. 